\title{
Flipped learning: should it replace didactic learning?
}

This article was published in the following Dove Press journal:

Advances in Medical Education and Practice

9 October 2017

Number of times this article has been viewed

\section{Abdirahman Osman \\ Seyed Ramin Jalal \\ Saeed Azizi}

Faculty of Medicine, St George's Hospital Medical School, London, UK
Correspondence: Abdirahman Osman Faculty of Medicine, St George's Hospital Medical School, Cranmer Terrace, London SWI7 ORE, UK

Tel +44 795073 I276

Email abdirahman97@hotmail.co.uk

\section{Dear editor}

We read with great interest the article by Pettit et $\mathrm{al}^{1}$ on the implementation of flipped learning. We wish to offer our perspective as medical students. The study concluded that a combination of lecture-based teaching accompanied with flipped learning activities appealed to most students. We find this response unsurprising. Pettit et al's ${ }^{1}$ article documents the reason - the need for a variation in teaching styles for different themes by millennial learners of the modern student community.

Petit et al ${ }^{1}$ highlight the importance of altering the pedagogical approach to further engage students. The extent to which the curriculum should incorporate a flipped course is where the discussion lies. We agree that themes that require a higher level of understanding should utilize the flipped learning model to some extent. This perspective is reflected by the downside of taking a traditional approach in teaching anatomy and medical diagnostics, where basic principles take up a significant portion of teaching time. A study by Rui et $\mathrm{al}^{2}$ provides quantitative evidence for the benefit of using a flipped classroom in the specific theme of diagnostics. What remains to be explored is whether or not the usage of flipped learning in other scenarios is just as effective.

Our exposure to flipped learning during medical school has been primarily through being taught anatomy and clinical skills. Reflecting on our experiences with flipped learning, we feel there are clear advantages and disadvantages. Pettit et $\mathrm{al}^{1}$ discuss the advantages, including learning flexibility and the ability to control the pace of learning. An advantage not highlighted in the article is that flipped learning creates an equal platform between lecturers and students, which can benefit student understanding. On the contrary, a notable disadvantage raised by Van Vliet et al' $\mathrm{s}^{3}$ article is the prevalence of non-attendees. From our observations, we found it is common practice that students who have not reviewed the necessary resources prior to the session decide not to attend the sessions, as they feel inadequately prepared. The negative implications of not attending sessions could mean that students fall behind, causing increased stress for students as assessments approach. ${ }^{4}$

The merits of flipped learning are well established and it has the potential to form the foundation of teaching in medical school. Being balanced, we believe it is important to acknowledge that flipped learning does not provide all the solutions for the limitations posed by traditional teaching. To address this, we propose a coupling between flipped learning and traditional lectured-based teaching, where students are provided with the preparatory reading in advance. This will then be followed by a traditional lecture, submit your manuscript Dovepress if in $D$ 
combined with an added interactive element such as retention tests. ${ }^{5}$ We believe the application of such an approach may hold the potential to allow educators to champion a more balanced and tailored approach to educating students.

\section{Disclosure}

The authors report no conflicts of interest in this communication.

\section{References}

1. Pettit RK, McCoy L, Kinney M, et al. What millennial medical students say about flipped learning. Adv Med Educ Pract. 2017;8:487-497.
2. Rui Z, Lian-Rui X, Rong-Zheng Y, Jing Z, Xue-Hong W, Chuan Z. Friend or Foe? Flipped classroom for undergraduate electrocardiogram learning: a randomized controlled study. BMC Med Educ. 2017;17(1):53.

3. Van Vliet E, Winnips JC, Brouwer N. Flipped-class pedagogy enhances student metacognition and collaborative-learning strategies in higher education but effect does not persist. CBE Life Sci Educ. 2015;14(3):ar26.

4. Sreeramareddy CT, Shankar PR, Binu VS, Mukhopadhyay C, Ray B, Menezes RG. Psychological morbidity, sources of stress and coping strategies among undergraduate medical students of Nepal. BMC Med Educ. 2007;7(1):26.

5. Datta R, Datta K, Venkatesh MD. Evaluation of interactive teaching for undergraduate medical students using a classroom interactive response system in India. Med J Armed Forces India. 2015;71(3):239-245.

Dove Medical Press encourages responsible, free and frank academic debate. The content of the Advances in Medical Education and Practice 'letters to the editor' section does not necessarily represent the views of Dove Medical Press, its officers, agents, employees, related entities or the Advances in Medical Education and Practice editors. While all reasonable steps have been taken to confirm the content of each letter, Dove Medical Press accepts no liability in respect of the content of any letter, nor is it responsible for the content and accuracy of any letter to the editor.

\section{Publish your work in this journal}

Advances in Medical Education and Practice is an international, peerreviewed, open access journal that aims to present and publish research on Medical Education covering medical, dental, nursing and allied health care professional education. The journal covers undergraduate education, postgraduate training and continuing medical education including emerging trends and innovative models linking education, research, and health care services. The manuscript management system is completely online and includes a very quick and fair peer-review system. Visit http://www.dovepress.com/testimonials.php to read real quotes from published authors.

Submit your manuscript here: http://www.dovepress.com/advances-in-medical-education-and-practice-journal 